\title{
ANALISIS KARAKTERISTIK DAN PENGGUNAAN OBAT PADA PASIEN ASMA DI PUSKESMAS REMAJA KOTA SAMARINDA
}

\author{
Andini Eka Bahari Putri, Nur Mita, Laode Rijai \\ Fakultas Farmasi, Universitas Mulawarman, Samarinda, Kalimantan Timur \\ Email : andinieka11@gmail.com
}

\begin{abstract}
Asthma is a disease with a wide spectrum of symptoms and the patient's symptoms which are reported to doctors are very diverse, depending on the perception of each patient. New approaches in the management of asthma patients in which patients can live freely without being bothered by the symptoms of the disease. The objective of this study was to determine the characteristics and the medication system in asthma patients at the Puskesmas Remaja Health Center Samarinda. This research was conducted by the retrospective method using medical records of patients in the Puskesmas Remaja Health Center Samarinda. The results, showed the highest percentage of asthma patient characteristics based on gender are 17 male patients (57\%), base on age are 15 patients of $30-50$ years old $(50 \%)$, and which the most significant comorbidities was tonsilitis as much as 5 patients $(50 \%)$. The most asthma prescribed by a doctor to a patient at the Puskesmas Remaja Health Center Samarinda was a combination of salbutamol and dexametason with oral route of treatment.
\end{abstract}

Keyword $\quad$ :Characteristic, medication system, asthma.

\begin{abstract}
ABSTRAK
Asma adalah penyakit dengan spekrum gejala yang luas dan gejala yang sering dilaporkan pasien kepada dokter sangat beragam, tergantung dari persepsi masing-masing pasien. Pendekatan terbaru dalam penatalaksanaan pasien asma yaitu pasien dapat hidup bebas tanpa terganggu oleh gejala penyakitnya. Tujuan penelitian ini adalah untuk mengetahui bagaimana karakteristik pasien dan penggunaan obat pada pasien asma di Puskesmas Remaja Samarinda. Penelitian ini dilakukan dengan metode retrospektif dengan menggunakan rekam medik pasien yang menjalani pengobatan di Puskesmas Remaja Samarinda. Hasil penelitian menunjukkan presentase tertinggi karakteristik pasien asma berdasarkan jenis kelamin yaitu jenis kelamin laki-laki sebesar 17 pasien (57\%), berdasarkan usia yaitu usia 30-50 tahun sebanyak 15 pasien (50\%), dan berdasarkan penyakit penyerta terbanyak yaitu tonsilitis sebanyak 5 pasien $(50 \%)$. Obat yang sering diresepkan oleh dokter kepada pasien di Puskesmas Remaja Samarinda dengan indikasi asma yaitu pemberian kombinasi obat salbutamol dan deksametason dengan rute pemberian oral.
\end{abstract}

Kata Kunci : karakteristik, pola pengobatan, asma 


\section{PENDAHULUAN}

Badan kesehatan dunia (WHO) memperkirakan 100-150 juta penduduk dunia menderita asma. Bahkan jumlah ini diperkirakan akan terus bertambah hingga mencapai 180.000 orang setiap tahun. Sumber lain menyebutkan bahwa pasien sudah mencapai 300 juta orang di seluruh dunia dan terus meningkat selama 20 tahun belakangan ini. Apabila tidak dicegah dan ditangani denga baik, maka diperkirakan akan terjadi peningkatan prevalensi yang lebih tinggi lagi pada masa yang akan datang serta mengganggu proses tumbuh kembang anak dan kualitas hidup pasien (Depkes RI, 2007).

Asma merupakan penyakit kronis saluran pernapasan yang ditandai oleh peningkatan reaktivitas terhadap berbagai stimulus, dan sumbatan saluran napas yang bisa kembali spontan atau dengan pengobatan yang sesuai. Meskipun pengobatan efektif telah dilakukan untuk menurunkan morbiditas karena asma, keefektifan hanya tercapai jika penggunaan obat telah sesuai. Berbagai upaya telah dilakukan oleh pemerintah untuk menanggulangi asma di masyarakat, namun tanpa peran serta masyarakat tentunya tidak akan dicapai hasil yang optimal. Mengingat prevalensi yang meningkat dari data yang ada dan berbagai faktor berperan dalam meningkatnya mortalitas asma sehingga memerlukan perawatan yang baik di rumah maupun di rumah sakit. Oleh karena itu perlu dilakukan penelitian tentang kajian penggunaan obat asma pada pasien asma. (Hartanto, 2001).

\section{RUMUSAN MASALAH}

Mengetahui karakteristik pasien penderita asma di Puskesmas Remaja Samarinda yang meliputi nama, jenis kelamin, usia, dan penyakit penyerta pasien, dan mengetahui penggunaan obat asma pada pasien asma di Puskesmas Remaja Samarinda yang meliputi nama obat, dosis dan rute pemberian obat.

\section{TUJUAN PENELITIAN}

Tujuan penelitian ini adalah:

1. Mengetahui karakteristik pasien penderita asma di Puskesmas Remaja Samarinda

2. Mengetahui penggunaan obat asma pada pasien asma di Puskesmas Remaja yang meliputi nama obat dan dosis pemberian

\section{METODE PENELITIAN}

\section{Jenis Penelitian}

Jenis penelitian ini adalah suatu Studi Analisis retrospektif.

\section{Tempat dan waktu penelitian}

Penelitian ini dilakukan di Puskesmas Remaja Samarinda dari bulan Januari - April 2015.

\section{Populasi Penelitian}

a. Lokasi Penelitian

Penelitian dilaksanakan di Puskesmas Remaja Samarinda

\section{b. Populasi Penelitian}

Populasi dalam penelitian ini adalah pasien asma yang menjalani rawat jalan di Puskesmas Remaja Samarinda 


\section{c. Teknik Penentuan Sampel Penelitian}

Kriteria yang akan dijadikan sampel adalah pasien yang memenuhi kriteria inklusi. Populasi penelitian yang termasuk dalam kriteria inklusi adalah semua pasien penderita asma, dan pasien tersebut memiliki data rekam medik yang lengkap. Kriteria eksklusi adalah pasien yang tidak memiliki data rekam medik yang lengkap.

\section{c. Teknik Pengumpulan Data}

\section{Data dan Sumber Data}

Data yang akan digunakan yaitu data sekunder berupa jenis kelamin, umur, nama obat, dan rute pemerian. Sumber data diperoleh dari pengambilan data menggunakan kartu rekam medik.

\section{Teknik Pengumpulan Data}

Teknik pengumpulan data dilakukan dengan menggunakan metode retrospektif berdasarkan data rekam medik pasien. Teknik pengumpulan data ini dilakukan dengan cara observasi setelah itu dilakukan pencatatan oleh peneliti.

\section{HASIL DAN PEMBAHASAN}

\section{Karakteristik Pasien Berdasarkan Jenis Kelamin}

Tabel 1

\begin{tabular}{|c|c|c|c|c|c|}
\hline \multicolumn{4}{|c|}{ Jenis Kelamin } & \multicolumn{2}{c|}{ Total } \\
\hline \multicolumn{2}{|c|}{ Laki-laki } & \multicolumn{2}{c|}{ Perempuan } & \multicolumn{2}{c|}{} \\
\hline Jumlah & Persentase & Jumlah & Persentase & Jumlah & persentase \\
\hline 17 & $57 \%$ & 13 & $43 \%$ & 30 & $100 \%$ \\
\hline
\end{tabular}

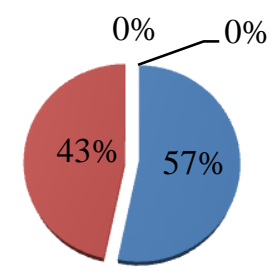

Laki-laki

Perempuan

Gambar

Berdasarkan hasil penelitian ini, didapatkan sebagian besar pasien asma berjenis kelamin laki-laki. Tabel 1 di atas menunjukkan bahwa dari 30 pasien asma 17 pesien berjenis kelamin laki-laki dan 13 pasien dengan jenis kelamin perempuan. Persentase dari seluruh pasien laki-laki yang menderita asma sebanyak $57 \%$ dan pasien perempuan yang menderita asma sebanyak 43\% dari seluruh pasien asma perempuan. Angka presentase tersebut bukan berarti bahwa laki-laki mempunyai resiko terkena penyakit asma lebih daripada wanita karena sampel yang digunakan pada penelitian ini sedikit dan hanya di ambil dari data rekam medik pasien yang berobat ke Puskesmas Remaja Samarinda. 
Sedangkan menurut literatur perempuan lebih rentan untuk menderita penyakit asma dibandingkan dengan laki-laki.

Berbagai sumber kepustakaan mengatakan bahwa penyebab prevalensi asma bronkial yang tinggi pada perempuan, masih belum dapat dipastikan karena berhubungan dengan multifaktorial. Perempuan dikatakan lebih rentan terhadap pejanan yang dapat memicu reaksi hipersensitifitas, dan merespon reaksi dengan lebih buruk dibandingka pada laki-laki (asthma control in woman). Faktor aktivitas dan stres psikologis juga berperan terhadap perburukan dan angka kekambuhan asma, dimana lebih rentan pada kaum perempuan. Berdasarkan penelitian Schatz et al terdapat beberapa hal yang menyebabkan peningkatan terjadinya asma pada perempua dibandingkan laki-laki, yaitu perbedaan hormon antara laki-laki dan perempuan, kecemasan dan depresi yang sering menyerang perempuan serta obesitas.

Penelitian Lim RH et al departemen imunologi dan biomolekular dari Universitas Harvard, mendapatkan bahwa prevalensi asma yang tinggi pada perempuan disebabkan oleh kadar esterogen yang beredar dalam tubuh dapat meningkatkan degranulasi eosnofil sehingga memudahkan terjadinya serangan asma. Kadar esterogen yang tinggi dapat berperan sebagai substansi proinflamasi (membantu/memicu inflamasi) terutama mempengaruhi sel mast, dimana sel mast merupakan sel yang berperan dalam memicu reaksi hipersensitivitas dengan melepaskan histamin dan mediator inflamasi lainnya, sehingga memperberat morbiditas asma pada pasien perempuan.

Penelitian Vrieze A et al mendapatkan bahwa, selain kadar esterogen yang tinggi, fluktuasi kadar esterogen yang besar pada saat menstruasi dan penggunaan kontrasepsi dan terapi sulih hormon pascamonopause juga ikut mempengaruhi keadaan asma bronkial pada perempuan. Fluktuasi kadar esterogen memicu reaksi inflamasi dan meningkatkan kadar substansi proinflamasi dalam tubuh, sehingga dapat memperburuk asma.

\section{Karakteristik Pasien Berdasarkan Usia}

Tabel

\begin{tabular}{ccc}
\hline Usia & Jumlah Pasien & Persentase $(\%)$ \\
\hline$<10$ tahun & 5 & $17 \%$ \\
$11-20$ tahun & 7 & $23 \%$ \\
$21-30$ tahun & 3 & $10 \%$ \\
$31-40$ tahun & 9 & $30 \%$ \\
$41-50$ tahun & 6 & $20 \%$ \\
\hline Total & 30 & $100 \%$ \\
\hline
\end{tabular}

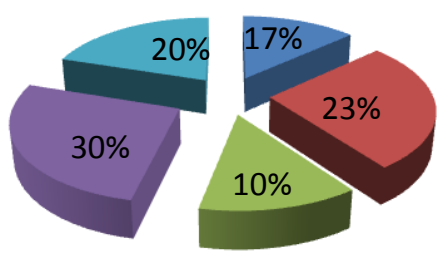

$$
\begin{aligned}
& \square<10 \text { th } \\
& \square 11 \text { th-20th } \\
& 21 \text { th-30th } \\
& -31 \text { th-40th } \\
& 41 \text { th-50th }
\end{aligned}
$$

Umur termuda yaitu umur 5 tahun dan umur tertua adalah umur 50 tahun. Kelompok terbanyak berumur 30 sampai 50 tahun yaitu berjumlah 15 pasien $(50 \%)$ sedangkan kelompok umur yang paling sedikit adalah kelompok umur 21 sampai 30 tahun yaitu 
sebanyak 3 pasien (10\%) seperti terlihat pada tabel 5.2 dan diagram 5.2. Berdasarkan hasil tersebut dapat dilihat bahwa penyakit asma tidak hanya menyerang orang dewasa saja, melainkan dapat juga dialami oleh anak yang berusia kurang dari 10 tahun, penelitian yang dilakukan Rengganis tahun 2008 melaporkan bahwa, laki-laki beresiko terkena asma saat anak-anak sebelum usia 14 tahun, prevalensi asma pada anak laki-laki adalah 1,5 sampai 2 kali dibandingkan anak perempuan. Hal tersebut dapat dilihat dari hasil yang didapat pada penelitian ini, dimana jumlah anak laki-laki yang berusia 5 sampai 10 tahun lebih banyak yaitu 4 pasien dan anak perempuan hanya ada 1 pasien.

Penelitian yang dilakukan oleh Atmoko tahun 2009, menunjukkan usia dewasa menempati distribusi terbesar yaitu sebanyak $67 \%$ dan usia lanjut 27,1\%. Hal ini menunjukkan bahwa asma bronkial lebih sering terjadi pada pasien dewasa yaitu berusia 20-55 tahun.

Menurut Postma DS, 2007, adanya perubahan hormonal yang terjadi pada masa dewasa memberikan kontribusi terhadap perkembangan asma. Penelitian yang dilakukan oleh lange et al tahun 2011 melaporkan bahwa hormon esterogen dapat meningkatkan produksi kortikosteroid yang berikatan dengan globulin, sedangkan hormon prodesteron dapat berkompetisi dengan hormon kortisol untuk berikatan pada sisi globulin tersebut. Hormon esterogen maupun progesteron dapat mempengaruhi level bebas kortisol yang menyebabkan penurunan jumlah kortisol. Akibat dari penurunan kortisol dapat menimbulkan penyempitan bronkus yang pada akhirnya menimbulkan serangan asma. Penelitian Postma DS tahun 2007, melaporkan bahwa hormon esterogen meningkatkan adhesi terhadap sel-sel endotel dipembuluh darah serta kombinasi antara hormon esterogen dan progesteron dapat meningkatkan degranulasi eosinofil sehingga memudahkan terjadinya serangan asma bronkial.

\section{Karakteristik Pasien Berdasarkan Penyakit Penyerta}

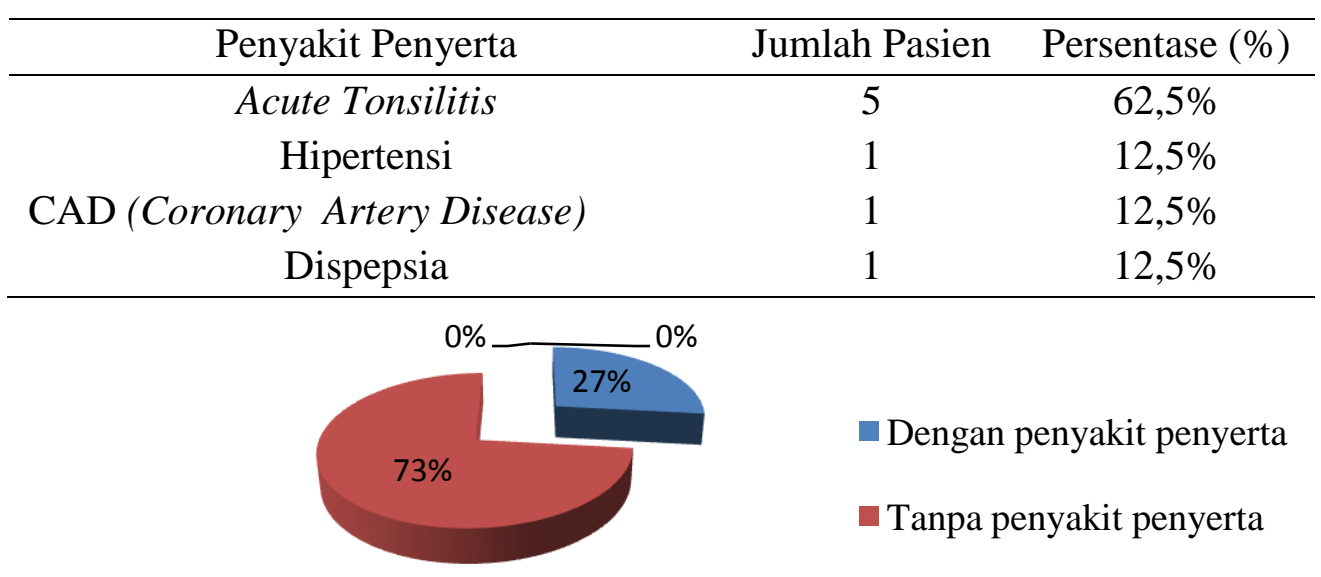

Pasien asma yang memiliki penyakit penyerta yang paling banyak adalah pasien dengan penyakit tonsilitis akut yaitu sebanyak 4 pasien (50\%). Menurut Smeltezer dan Bare tahun 2001, Tonsil terdiri atas limfatik dan terletak pada kedua sisi orofaring. Keduanya sering menjadi tempat terjangkitnya infeksi akut. Streptokokus grup A adalah organisme paling umum yang berkaitan dengan tonsilitis dan adenoid. Tonsilitis kronik kurang umum dan mungkin disalah artikan dengan kelainan lain seperti alergi, asma, dan sinusitis. 
Menurut Reeves tahun 2001, Tonsilitis merupakan inflamasi atau pembengkakan akut pada tonsil atau amandel. Hiphertropi yang disebabkan oleh infeksi, bisa menyebabkan tonsil membengkak sehingga bisa menghambat keluar masuknya udara. Biasanya penderita tonsil ini mengalami sakit tenggorokan, sakit ketika menelan, parinx mengalami edema dan berwarna merah.

Menurut Widodo Judarwanto mengenai gangguan penyakit penyerta penderita asma, penyakit penyerta yang dialami oleh pasien asma merupakan reaksi alergi yang dapat mengganggu beberapa sistem dan organ tubuh. Gejala tergantung dari organ atau sistem tubuh, bisa terpengaruh bija juga melemah. Penderita asma juga sering disertai dengan gangguan alergi pada organ tubuh lainnya seperti sering disertai hay fever, rinitis, sinusitis, dermatitis, migrain, dan gangguan hormonal. Pada gangguan saluran kencing didapatkan gejala seperti sering kencing. Gangguan saluran cerna yang sering didapatkan adalah gastroesofageal refluk, nyeri perut berulang, mual, bibir kering, sariawan, konstipasi, mudah diare, dan gangguan cerna lainnya. Pada sistem otot tulang didapatkan keluhan myalgia atau artralgia pada kaki, tangan, atau pada leher dan nyeri dada. Pada gangguan sistem vaskular didapatkan gejala palpitasi, mudah pingsan, kolap dan hipotensi.

Berdasarkan hasil dari penelitian ini dapat dilihat bahwa adanya kesesuaian penyakit penyerta yang dialami oleh pasien asma di Puskesmas Remaja Samarinda dengan penyakit penyerta yang kemungkinan dapat di alami oleh pasien asma pada umumnya. Dari 30 pasien, terdapat 8 pasien yang memiliki penyakit penyerta. Dimana penyakit penyerta adalah penyakit yang telah ada bersama penyakit utama. Diantaranya terdapat pada pasien yang telah memiliki riwayat penyakit penyerta seperti acute tonsilitis, hipertensi, diabetes mellitus, CAD (Coronary Artery Disease), dan dispepsia.

\section{Karakteristik Penggunaan Obat}

\begin{tabular}{lcccc}
\hline No & Golongan Obat & Jenis Obat & Jumlah & Persentase (\%) \\
\hline 1 & Beta 2 agonis kerja & Salbutamol & 30 & $100 \%$ \\
& singkat & & & \\
2 & kortikosteroid & Dexametason & 29 & $96,67 \%$ \\
\hline
\end{tabular}

Obat yang diresepkan oleh dokter kepada pasien di Puskesmas Remaja Samarinda dengan indikasi asma yaitu pemberian obat salbutamol dengan tambahan pemberian obat dexametason dengan rute pemberian oral. Salbutamol merupakan obat golongan Beta 2 agonis kerja singkat. Mekanisme kerja agonis reseptor $\beta$-adrenergik kerja singkat sebagai anti asma dipastikan berkaitan dengan relaksasi langsung otot-otot polos saluran napas dan bronkodilatasi yang diakibatkannya. Peresepan salbutamol untuk indikasi asma di Puskesmas Remaja Samarinda, pemberiannya ditambahkan dengan pemberian deksametason yang diberikan melalui rute oral. Deksametason merupakan obat golongan kortikosteroid. Deksametason, seperti kortikosteroid lainnya memiliki efek anti inflamasi dan anti alergi dengan pencegahan pelepasan histamine (Pharmaceutical care untuk penyakit asma, 2007).

Berdasarkan Pharmaceutical care untuk penyakit asma, pemberian terapi tambahan merupakan suatu metode yang banyak digunakan dalam penanganan penyakit asma untuk 
menunjang kerja dari obat tersebut. Terapi tambahan ini digunakan pada pasien dengan riwayat asma yang sedang sampai berat, dimana pengobatan dengan obat tunggal kurang berhasil.

Peresepan obat untuk pasien asma di Puskesmas Remaja rata-rata menggunakan obat salbutamol dengan obat tambahan yaitu deksametason. Sedangkan, obat-obat lainnya diberikan untuk mengobati keluhan dan penyakit penyertanya. Hasil dari penelitian ini dapat dilihat bahwa peresepan salbutamol dengan tambahan dexametason sudah tepat, karena efek kerja dari dexametason yang dapat membantu efek dari salbutamol untuk menghasilkan efek bronkodilatasi pada saluran pernafasan.

\section{Dosis dan Rute Pemberian Obat}

Dosis merupakan takaran dan jumlah obat yang diberikan pada satu waktu. Frekuensi adalah jumlah banyaknya hasil yang diperoleh. Rute pemberian obat terutama ditentukan dari sifat dan tujuan dari penggunaan obat sehingga dapat memberikan efek yang tepat.

Hasil penelitian ini menunjukkan obat yang di resepkan kepada pasien yaitu salbutamol, dexametason. Dosis salbutamol adalah $2 \mathrm{mg}$ da $4 \mathrm{mg}$, dalam penelitian ini pengobatan pada pasien asma dosis salbutamol yang paling banyak diberikan oleh dokter adalah dosis $2 \mathrm{mg}$. Pemberian dosis obat golongan kortikosteroid yaitu dexametason 0,5. Berdasarkan Pharmaceutical Care untuk Penyakit Asma, hasil tersebut sudah sesuai dengan literatur yang menunjukkan dosis pemberian untuk tablet salbutamol adalah $2 \mathrm{mg}$, dan dosis pemberian untuk tablet dexametason adalah $0,5 \mathrm{mg}$.

\section{Kesimpulan}

Berdasarka hasil penelitian karakteristik dan penggunaan obat pada pasen asma di Puskesmas Remaja Samarinda, dapat disimpulkan bahwa:

1. Berdasarkan karakteristik pasien, jumlah pasien laki-laki yang menderita asma lebih banyak yaitu 17 pasien (57\%) dibandingkan dengan pasien perempuan yaitu 13 pasien (43\%).

2. Berdasarkan penggunaan obat, golongan obat yang paling banyak digunakan yaitu golongan $\mathrm{B}_{2}$ agonis kerja singkat dan golongan kortikosteroid.

3. Obat golongan $B_{2}$ agonis kerja singkat yang digunakan yaitu salbutamol $2 \mathrm{mg}$ dan obat golongan kortikosteroid yang digunakan yaitu deksametason $0,5 \mathrm{mg}$.

\section{Daftar Pustraka}

Asthma Control in Woman (online) dikunjungi 22 Oktober 2015, tersedia di http://www.pulmonaryreview.com

Bare BG, Smeltzer SC. 2001. Buku Ajar Keperawatan Medikal Bedah. EGC: Jakarta.

Depkes RI. 2007. Pedoman Pengendalian Penyakit asma. Departemen Kesehatan RI: Jakarta.

Depkes RI. 2007. Pharmaceutical Care untuk Penyakit Asma. Direktorat Bina Farmasi komunitas dan Klinik.

Hartanto, H., 2001. Farmakologi: Ulasan Bergambar Edisi II. Widya Medika: Jakarta.

Lim RH, et al. 2008. Sexual Tension in the Airways: the Puzzling Duality of Esterogen in Asthma. USA: American Journal of Respiratory Cell and Molecular Biology.

Reeves CJ, Roux G, dan Lockhart R. 2001. Keperawatan Medikal Bedah, Buku 1 (penerjemah Joko Setyono). Salemba Medika: Jakarta.

Rengganis, Iris. 2008. Diagnosis dan Tatalaksana Asma Bronkial. Majalah Kedokteran Indonesia Vol. 58 No. 11. 
Schatz M, Camargo CA. The Relatationship of Sex to Asthma Prevalence, Health Care Utilization, and Medication in a Large Managed Care Organization. Ann Allergy Asthma Immunol.

Vrieze A, Postma DS, Kertsjens HA. 2007. Perimenstrual Asthma: a Syndrome Without Known Cause or Cure. Journal Allergy Clin Immunol Norway. 